\title{
Recent advances in managing differentiated thyroid cancer
}

\section{[version 1; peer review: 2 approved]}

\author{
Livia Lamartina, Giorgio Grani(iD), Cosimo Durante, Sebastiano Filetti (iD)
}

Dipartimento di Medicina Interna e Specialità Mediche, Università di Roma "Sapienza", Viale del Policlinico 155, 00161 Rome, Italy

V1 First published: 18 Jan 2018, 7(F1000 Faculty Rev):86

https://doi.org/10.12688/f1000research.12811.1

Latest published: 18 Jan 2018, 7(F1000 Faculty Rev):86

https://doi.org/10.12688/f1000research.12811.1

\section{Abstract}

The main clinical challenge in the management of thyroid cancer is to avoid over-treatment and over-diagnosis in patients with lower-risk disease while promptly identifying those patients with more advanced or high-risk disease requiring aggressive treatment. In recent years, novel clinical and molecular data have emerged, allowing the development of new staging systems, predictive and prognostic tools, and treatment approaches. There has been a notable shift toward more conservative management of low- and intermediate-risk patients, characterized by less extensive surgery, more selective use of radioisotopes (for both diagnostic and therapeutic purposes), and less intensive follow-up. Furthermore, the histologic classification; tumor, node, and metastasis (TNM) staging; and American Thyroid Association risk stratification systems have been refined, and this has increased the number of patients in the low- and intermediate-risk categories. There is now a need for new, prospective data to clarify how these changing practices will impact long-term outcomes of patients with thyroid cancer, and new follow-up strategies and biomarkers are still under investigation. On the other hand, patients with more advanced or high-risk disease have a broader portfolio of options in terms of treatments and therapeutic agents, including multitarget tyrosine kinase inhibitors, more selective BRAF or MEK inhibitors, combination therapies, and immunotherapy.

\section{Keywords}

Thyroid cancer, radioisotopes, TMN staging

\section{Open Peer Review}

Approval Status

1

2

version 1

18 Jan 2018

Faculty Reviews are review articles written by the prestigious Members of Faculty Opinions. The articles are commissioned and peer reviewed before publication to ensure that the final, published version is comprehensive and accessible. The reviewers who approved the final version are listed with their names and affiliations.

1. Matthew Ringel, The Ohio State University Medical Center, Columbus, USA

2. Iain Nixon, NHS Lothian, Edinburgh, UK Any comments on the article can be found at the end of the article. 
Corresponding author: Sebastiano Filetti (sebastiano.filetti@uniroma1.it)

Author roles: Lamartina L: Writing - Original Draft Preparation, Writing - Review \& Editing; Grani G: Writing - Original Draft Preparation, Writing - Review \& Editing; Durante C: Writing - Original Draft Preparation, Writing - Review \& Editing; Filetti S: Supervision, Writing - Original Draft Preparation, Writing - Review \& Editing

Competing interests: No competing interests were disclosed.

Grant information: The author(s) declared that no grants were involved in supporting this work.

Copyright: ๑ 2018 Lamartina L et al. This is an open access article distributed under the terms of the Creative Commons Attribution License, which permits unrestricted use, distribution, and reproduction in any medium, provided the original work is properly cited.

How to cite this article: Lamartina L, Grani G, Durante C and Filetti S. Recent advances in managing differentiated thyroid cancer [version 1; peer review: 2 approved] F1000Research 2018, 7(F1000 Faculty Rev):86 https://doi.org/10.12688/f1000research.12811.1

First published: 18 Jan 2018, 7(F1000 Faculty Rev):86 https://doi.org/10.12688/f1000research.12811.1 


\section{Introduction}

The incidence of differentiated thyroid cancer (DTC) continues to rise worldwide, mostly because of the growing use of powerful diagnostic tools that permit the discovery of an increasing number of small papillary thyroid cancers (PTCs). Mortality from DTC, however, has changed minimally over the past five decades: the vast majority of patients with DTC have indolent tumors. The main clinical challenge is to avoid over-diagnosis in patients with low-risk disease or benign thyroid nodules while promptly identifying those patients with more advanced or high-risk tumors that require aggressive treatment approaches. In recent years, we have witnessed the emergence of new clinical and molecular data that have allowed the development of new staging systems, new predictive and prognostic tools, and new approaches to treatment. Here, we will review the main advances regarding the staging and management of DTC.

\section{Pathologic definition and staging systems}

The fourth edition of the World Health Organization histologic classification of endocrine tumors, published in June $2017^{1}$, contains important revisions, which may have a broad impact on clinical practice. First, the follicular-derived neoplasms now include a new entity within the group of tumors with borderline histological features: the non-invasive follicular thyroid tumor with papillary nuclear features (NIFTP) ${ }^{2,3}$, an encapsulated follicular-variant PTC with no evidence of capsular or vascular invasion. NIFTPs may account for up to $20 \%$ of the tumors previously classified as PTCs. The word "cancer" has been eliminated from the definition of NIFTP to underline its excellent prognosis: no adverse outcomes (such as cancer-related death, distant or regional metastases, and structural or biochemical recurrence) have been recorded for these tumors. The explicitly stated objective is to reduce the intensity of treatment and follow-up and the psychological consequences of the diagnosis of cancer. This entity was first proposed by an international panel of pathologists and other professionals and has been endorsed by the American Thyroid Association (ATA). However, the seemingly excellent outcomes still need to be confirmed in long-term prospective studies. The current evidence is retrospective and of only moderate quality ${ }^{2}$. Other relevant changes include the identification of 15 PTC variants and the distinction of follicular thyroid cancers (FTCs) into three subgroups (minimally invasive FTCs with capsular invasion only, encapsulated angioinvasive FTCs, and widely invasive FTCs), which reflect the prognostic relevance of vascular invasion. Given its unique molecular profile $^{4}$, the oncocytic variant is now considered a separate entity and is referred to as Hürthle cell carcinoma. Poorly differentiated thyroid cancer is also a separate entity, in accordance with the Turin criteria $^{5,6}$.

The American Joint Cancer Committee/Union Internationale Contre le Cancer TNM staging system for thyroid cancer takes into account patient age, the size and extent of the primary thyroid tumor $(\mathrm{T})$, lymph node involvement $(\mathrm{N})$, and the presence of distant metastases (M). This system is aimed at predicting mortality (not recurrences). The eighth edition of this staging system contains important modifications. The age cutoff was raised from 45 to 55 years $^{7}$, the presence of minimal extrathyroidal extension is no longer relevant for the $\mathrm{T}$ classification, and the tumor stages have been redistributed (Table 1 and Table 2). Regional lymph node metastases or the presence of gross extrathyroidal extension limited to strap muscle no longer mandate stage III but stage II. The presence of macroscopic invasion beyond strap muscle (subcutaneous tissue, larynx, trachea, esophagus in T4a tumors or carotid artery, prevertebral fascia or mediastinal vessels in T4b tumors) is an unfavorable prognostic factor. The overall goal of these modifications is to improve the accuracy of the system's prediction of mortality $^{8}$, restricting the assignment of higher risk to a small subset of patients (5-10\%) with tumors classified as stage III (pT4a, any N, M0) or stage IV (pT4b, any $\mathrm{N}, \mathrm{M} 0$, and M1). Implementation of the eighth edition revisions is expected to result in the down-staging of approximately $30-40 \%$ of patients with thyroid cancer ${ }^{9,10}$.

In the 2015 edition of its practice guidelines, the ATA also revised its system for stratifying the risk of recurrent disease. The new variables considered include new pathologic features of the tumor (for example, histopathological variant, vascular invasion, number of metastatic lymph nodes, size of the largest metastatic lymph node, and the presence of extranodal extension) as well as its molecular characteristics (mutational status of $B R A F$ and the TERT promoter $^{11}$, when available $)^{12}$. These changes are expected to allow more precise estimates of the likelihood of recurrence.

The dynamic risk classification process used during follow-up assigns patients to one of four subgroups and may be modified at each follow-up examination: responses to therapy are classified as excellent, biochemically incomplete, structurally incomplete, or indeterminate response.

\section{Management strategies}

Current international guidelines advocate personalized decisionmaking-based on the risk of recurrence and disease-specific death-regarding the extent of surgery, the use of radioactive iodine (RAI) therapy, the intensity and length of follow-up, and the degree of thyroid-stimulating hormone (TSH) suppression.

\section{Active surveillance}

The 2015 ATA guidelines include active surveillance among the management options for small subcentimeter PTCs. In pivotal Japanese studies, this strategy appeared to be both safe and effective ${ }^{13,14}$ : after 10 years, very few patients had experienced tumor growth $(8 \%)$, and the development of lymph node metastases was even less common (4\%). Age below 40 at diagnosis was an independent risk factor for disease progression $^{15}$. In terms of cures, delayed surgical treatment of these tumors was as effective as immediate treatment ${ }^{15}$.

In a study conducted in the United States, 291 patients with cytologically suspicious or malignant thyroid nodules (Bethesda class $\mathrm{V}$ or VI) measuring $1.5 \mathrm{~cm}$ or less were managed with active surveillance for a median of two years ${ }^{16}$. The percentages of tumors displaying growth were $2.5 \%$ at two years and $12 \%$ at five years. Independent predictors of growth were age under 50 years and clinical judgment as "inappropriate for active surveillance" ${ }^{16}$. The latter label may be applied on the basis of nodule-related features (subcapsular location adjacent to the 
Table 1. AJCC TNM seventh and eighth edition: definitions.

\section{Tumor}

T1a: tumor $\leq 1 \mathrm{~cm}$ limited to the thyroid

T1b: tumor $>1 \mathrm{~cm}$ but $\leq 2 \mathrm{~cm}$ limited to the thyroid

T2: tumor $>2 \mathrm{~cm}$ but $\leq 4 \mathrm{~cm}$ limited to the thyroid

T3: tumor $>4 \mathrm{~cm}$ limited to the thyroid or minimal extrathyroid extension (for example, perithyroidal soft tissues or sternothyroid muscle) from a tumor of any size

T4a: gross extrathyroidal extension invading subcutaneous soft tissues, larynx, trachea, esophagus, or recurrent laryngeal nerve from a tumor of any size

T4b: gross extrathyroidal extension invading prevertebral fascia or encasing the carotid artery or mediastinal vessels from a tumor of any size
T1a: tumor $\leq 1 \mathrm{~cm}$ limited to the thyroid

T1b: tumor $>1 \mathrm{~cm}$ but $\leq 2 \mathrm{~cm}$ limited to the thyroid

T2: tumor $>2 \mathrm{~cm}$ but $\leq 4 \mathrm{~cm}$ limited to the thyroid

T3a: tumor $>4 \mathrm{~cm}$ limited to the thyroid

T3b: gross extrathyroidal extension invading only strap muscles (sternohyoid, sternothyroid, thyrohyoid, omohyoid) from a tumor of any size

T4a: gross extrathyroidal extension invading subcutaneous soft tissues, larynx, trachea, esophagus, or recurrent laryngeal nerve from a tumor of any size

T4b: gross extrathyroidal extension invading prevertebral fascia or encasing the carotid artery or mediastinal vessels from a tumor of any size

\section{Node}

Nx: regional lymph nodes cannot be assessed

N0: no evidence of locoregional lymph node metastasis
Nx: regional lymph nodes cannot be assessed

NOa: one or more cytologically or histologically confirmed benign lymph nodes

NOb: no radiologic or clinical evidence of locoregional lymph node metastasis

N1a: ipsilateral or bilateral metastasis to level VI or VII (pretracheal, paratracheal, or prelaryngeal/Delphian, or upper mediastinal) lymph nodes; this can be unilateral or bilateral disease

N1b: metastasis to unilateral, bilateral, or contralateral lateral neck lymph nodes (levels I, II, III, IV, or V) or retropharyngeal lymph nodes

N1b: metastasis to unilateral, bilateral, or contralateral lateral neck lymph nodes (levels I, II, III, IV, or V) or retropharyngeal or superior mediastinal lymph nodes (level VII)

\section{Metastasis}

M0: no distant metastasis

M0: no distant metastasis

M1: distant metastasis

M1: distant metastasis

AJCC, American Joint Cancer Committee; TNM, tumor, node, and metastasis.

Table 2. AJCC TNM seventh and eighth edition: stage.

\begin{tabular}{|c|c|c|c|c|c|c|c|}
\hline Seventh edition & Age $<4$ & years & & Eighth edition & Age $<5$ & years & \\
\hline I & Any $T$ & Any N & MO & I & Any $T$ & Any N & MO \\
\hline II & Any $T$ & Any N & M1 & ॥ & Any $T$ & Any N & M1 \\
\hline Seventh edition & Age $\geq 4$ & years & & Eighth edition & Age $\geq 5$ & years & \\
\hline I & $\mathrm{T} 1 \mathrm{a} / \mathrm{b}$ & No & MO & । & $\begin{array}{l}\mathrm{T} 1 \mathrm{a} / \mathrm{b} \\
\mathrm{T} 2\end{array}$ & $\begin{array}{l}\text { NO/NX } \\
\text { NO/NX }\end{array}$ & $\begin{array}{l}\text { MO } \\
\text { MO }\end{array}$ \\
\hline II & T2 & No & MO & II & $\begin{array}{l}\text { T1a/b } \\
\text { T2 } \\
\text { T3a/b }\end{array}$ & $\begin{array}{l}\text { N1a/b } \\
\text { N1a/b } \\
\text { Any N }\end{array}$ & $\begin{array}{l}\text { MO } \\
\text { MO } \\
\text { MO }\end{array}$ \\
\hline III & $\begin{array}{l}\text { T1a/b } \\
\text { T2 } \\
\text { T3 }\end{array}$ & $\begin{array}{l}\text { N1a } \\
\text { N1a } \\
\text { No, N1a }\end{array}$ & $\begin{array}{l}\text { MO } \\
\text { MO } \\
\text { MO }\end{array}$ & III & $\mathrm{T} 4 \mathrm{a}$ & Any N & MO \\
\hline IVa & $\begin{array}{l}\text { T1a/b } \\
\text { T2 } \\
\text { T3 } \\
\text { T4a }\end{array}$ & $\begin{array}{l}\text { N1b } \\
\text { N1b } \\
\text { N1b } \\
\text { N0, N1a, N1b }\end{array}$ & $\begin{array}{l}\text { MO } \\
\text { MO } \\
\text { MO } \\
\text { MO }\end{array}$ & IVa & $\mathrm{T} 4 \mathrm{~b}$ & Any N & MO \\
\hline $\mathrm{IVb}$ & $\mathrm{T} 4 \mathrm{~b}$ & Any N & MO & $\mathrm{IVb}$ & Any $T$ & Any N & M1 \\
\hline IVc & Any $T$ & Any $T$ & M1 & - & - & - & - \\
\hline
\end{tabular}

AJCC, American Joint Cancer Committee; TNM, tumor, node, and metastasis. 
recurrent laryngeal nerve [RLN], suspicion of extrathyroidal extension, and invasion of the RLN or trachea-all three of which can be difficult to exclude on neck ultrasound [US] - fine-needle aspiration [FNA] cytology findings suggestive of an aggressive histotype, and a documented increase in size of at least $3 \mathrm{~mm}$ in a confirmed PTC) or patient-related factors (metastatic disease, age below 18 years, refusal of the surveillance-alone approach, poor adherence to the follow-up protocol) or physician-related factors (limited experience with thyroid cancer management or neck US or both) or a combination of these factors ${ }^{17}$.

Other observational clinical trials to evaluate the "active surveillance" approach in subcentimeter PTCs are underway in Korea and Israel (NCT02952612, NCT02938702, and NCT02609685). Also, there is a need for biomarkers that can identify those rare microcarcinomas that are likely to grow, so they can be promptly referred for surgery.

\section{Individualized surgical approaches}

According to the ATA guidelines ${ }^{12}$, thyroid lobectomy (TL) may be used for low-risk, intrathyroidal tumors up to $4 \mathrm{~cm}$ in size with no lesions in the contralateral lobe. Total thyroidectomy (TT) was previously considered the preferred approach for these tumors. In a retrospective analysis of 52,173 cases in the Surveillance Epidemiology and End Results (SEER) database, TL for tumors measuring at least $1 \mathrm{~cm}$ was associated with small but statistically significant increases in the risks for recurrence (9.8\% versus $7.7 \%$ ) and mortality ( $2.9 \%$ versus $1.6 \%$ ) compared with $\mathrm{TT}^{18}$. A recent retrospective analysis with a more extensive risk stratification found no such difference in terms of overall survival ${ }^{19}$, but, in another meta-analysis, the risk of recurrence after TL was significantly higher than that after TT $(8.3 \% \text { versus } 4.4 \% ; p<0.01)^{20}$. It is worth noting that tumor recurrence in the contralateral lobe has been observed in $5 \%$ of patients treated with $\mathrm{TL}^{21}$ and that benign nodule relapse is reported in $20-50 \%^{22,23}$. Levothyroxine treatment has been reported to prevent benign nodule relapse, but the evidence for this effect is limited ${ }^{24}$.

TL offers several advantages over TT. First, the rate of side effects is lower with TL. It virtually eliminates the risks of permanent hypoparathyroidism and bilateral RLN palsy ${ }^{25}$ and reduces the rates of permanent unilateral RLN palsy $(0.6 \%$ in TL versus $1.3 \%$ in TT) $)^{25}$. Second, surgical hypothyroidism after TT requires lifelong levothyroxine (LT4) replacement therapy. The rate of hypothyroidism after TL varies from 23.6 to $47 \%$, 26,27 and patients with a normal serum TSH level may not require LT4 treatment at all. TL and TT are also believed to have differential effects on the patient's quality of life. However, two relatively small studies have failed to detect any difference ${ }^{28,29}$ and thus further investigation of this issue is needed.

The ATA guidelines do not advocate prophylactic central neck dissection for low-risk patients ${ }^{12}$ despite the high frequency of subclinical lymph node metastasis in $\mathrm{DTC}^{30}$. In fact, microscopic lymph node metastases that are not clinically detected before surgery have a questionable role in patient outcome ${ }^{31}$, and central compartment neck dissection carries an increased rate of surgical complications, hypoparathyroidism in particular $^{32,33}$. In a prospective study of patients with no preoperative evidence of lymph node metastasis who were randomly assigned to undergo TT alone or TT with central compartment neck dissection, no difference in outcomes was found after five years of follow-up ${ }^{32}$.

\section{Radioiodine remnant ablation: selective use}

In the past, routine use of RAI ablation therapy after surgery was justified first by the need to eliminate residual normal thyroid tissue, to achieve an undetectable serum thyroglobulin ( $\mathrm{Tg}$ ) level. It also allowed the identification of persistent neoplastic tissue with $\mathrm{a}^{131} \mathrm{I}$ whole-body scan (WBS) and was likely to destroy any occult nests of neoplastic cells, thereby improving long-term outcomes. These indications have been questioned in recent years ${ }^{12,34,35}$. The ATA guidelines now recommend selective use of RAI based on individual risk ${ }^{12}$. Claiming uncertainties and ambiguities in the evidence, the European Association of Nuclear Medicine refused to endorse these recommendations ${ }^{36}$ and noted that there are no prospective, controlled study data that allow us to identify the patients with low-risk DTC who may not benefit from RAI ablation. However, the Association did not emphasize that a treatment should be given only in patients in whom it may be beneficial and did not acknowledge that uncertainties persist concerning benefits of RAI administration in low- and intermediate-risk patients.

It is generally agreed that RAI has no role in the management of patients with intra-thyroidal microcarcinomas. In other low- and intermediate-risk patients, the decision to ablate can be based on individual prognostic factors and on the serum $\mathrm{Tg}$ level measured 6 weeks after surgery either on LT4 treatment with a sensitive assay or following recombinant human TSH (rhTSH) injections. An undetectable or a low serum Tg level at that time supports a decision to avoid RAI administration. When it is indicated, it should consist of the administration of $1.1 \mathrm{GBq}$ following rhTSH injections ${ }^{37}$.

Two randomized clinical trials in Europe are enrolling low-risk patients and aim to obtain reliable data on the indications for post-operative RAI administration. In the ESTIMABL2 trial (NCT01837745) being conducted in France, 750 patients with a $\mathrm{T} 1 \mathrm{bN} 0, \mathrm{Nx}$ tumor will be randomly assigned to post-operative ablation with an activity of $30 \mathrm{mCi}$ after rhTSH stimulation or simple follow-up. The IoN trial in the UK (NCT01398085) has a similar design. The primary outcomes in the two studies are disease-free survival rates at 3 and 5 years, respectively.

\section{Follow-up tools}

The main tools used for the follow-up of DTC are neck US and serum $\mathrm{Tg}$ determination ${ }^{38}$. Undetectable serum $\mathrm{Tg}$ levels can reliably identify disease-free patients and have a negative predictive value close to $100 \%$. In contrast, early minimally detectable levels have a low positive predictive value: the majority of patients with these findings remain free of structural disease during prolonged follow-up ${ }^{39}$. Tg trends over time-instead of absolute alues_-should be monitored: declining levels are reassuring, whereas increases suggest the presence of growing thyroid tissue (normal or neoplastic) $^{40}$. In the presence of $\mathrm{Tg}$ autoantibodies (TgAbs), serum Tg levels determined by immunometric assays 
may be falsely low. In these cases, management can be guided by the temporal trends in the $\mathrm{TgAb}$ titers themselves ${ }^{41}$. Novel biomarkers are emerging as replacements for serum $\mathrm{Tg}$ in these difficult cases, such as circulating microRNAs and other nucleic acids, but still need to be standardized and clinically validated ${ }^{42-44}$. The use of mass spectrometry for measuring serum Tg levels in the presence of $\mathrm{TgAb}$ also needs to be validated ${ }^{45,46}$. Sensitive $\mathrm{Tg}$ assays that can detect serum concentrations as low as $0.1 \mathrm{ng} / \mathrm{mL}$ are currently used and provide similar information on disease status as rhTSH-stimulated Tg obtained in the past with assays that had a sensitivity of $1 \mathrm{ng} / \mathrm{mL}$. RhTSH-stimulated Tg levels are now measured during the follow-up only in those few patients with low but detectable serum $\mathrm{Tg}$ on LT4 treatment ${ }^{47}$. In these patients, a substantial increase in the stimulated $\mathrm{Tg}$ level may indicate the presence of neoplastic tissue.

Neck US provides useful information. PTC almost always spreads first to the cervical lymph nodes, where it can be identified sonographically using specific criteria ${ }^{48}$, thus eliminating the need for diagnostic ${ }^{131} \mathrm{I}$ WBS. US is more cost-effective, eliminates radiation exposure, and has no adverse effects. Surgical treatment of lymph node metastases is recommended for lesions with smaller diameters exceeding $10 \mathrm{~mm}$ (for lateral $\mathrm{N1}$ ) or $8 \mathrm{~mm}$ (for central $\mathrm{N} 1$ ), and there is no need for discovering small N1 of only a few millimeters in diameter. However, US is notoriously operatordependent, and some findings are non-specific and classified as indeterminate. Lesions with such features display significantly lower rates of persistence and growth than those with more suspicious US characteristics ${ }^{49}$. Suspicious findings can be confirmed by US-guided FNA with cytologic assessment and assay of $\mathrm{Tg}$ in the needle-washout fluid ${ }^{50}$. Distant metastases are rare in patients with negative findings on neck US. However, in the presence of rising $\mathrm{Tg}$ levels or suspicious clinical features, second-line functional (diagnostic ${ }^{131} \mathrm{I}$ WBS and 18-fluorodeoxyglucose positron emission tomography scan) or cross-sectional (computed tomography or magnetic resonance imaging) imaging studies may be performed $^{51}$.

Risk assessment is a dynamic process: the response to therapy is re-assessed on the basis of findings at each follow-up visit and expressed as excellent, indeterminate, biochemically incomplete, or structurally incomplete ${ }^{12,39,52}$. During long-term follow-up, even patients who initially displayed a high risk of persistent or recurrent disease can be re-classified as having lower-risk disease, and their follow-up program can be less intensive than originally planned. Lifelong surveillance is still recommended ${ }^{12}$. However, over $75 \%$ of recurrent lesions are identified within the first five years of follow-up, and late recurrence is very unlikely in low- or intermediate-risk patients with excellent responses to treatment ${ }^{53}$.

TSH stimulates the proliferation of normal and neoplastic thyrocytes ${ }^{54}$, and levothyroxine treatment significantly reduces DTC recurrence and cancer-related mortality ${ }^{55}$. The optimal TSH level is unclear. TSH suppression increases the risk for atrial fibrillation and osteoporosis in older patients and the risk of angina in patients with ischemic heart disease ${ }^{56}$. Suppressive therapy should take into account both the likelihood of complications and the risk of increasing tumor cell proliferation. For this reason, levothyroxine treatment is no longer recommended for low- and intermediate-risk patients with no evidence of disease. The goal in these cases is a serum TSH level within the normal range. Suppressive therapy is advocated only in patients with structural disease and no contraindications ${ }^{12}$.

\section{Treatment of distant metastases}

RAI $\left.{ }^{131} \mathrm{I}\right)$ is currently the first-line treatment for distant metastases that are RAI-avid. Traditionally, thyroid hormone withdrawal has been the preferred method of preparation for this type of patient because it is associated with higher neoplastic tissue uptake and slower clearance of RAI than that achieved with rhTSH preparation. Observational data have suggested that rhTSH preparation may also be effective in terms of response to treatment in these patients ${ }^{57}$, but the evidence in support of this conclusion is currently insufficient to recommend rhTSH use in patients with metastatic DTC ${ }^{12}$. The activity of RAI for the treatment of distant metastases can be calculated dosimetrically or a fixed empiric dose can be used. A large retrospective study of DTC patients with distant metastases found similar overall survival with the two approaches ${ }^{58}$ after adjustments for age and tumor burden ${ }^{59}$.

\section{Radioactive iodine-refractory disease}

RAI-refractory DTC is defined as persistent neoplastic tissue that does not take up RAI; disease characterized by heterogeneous RAI uptake (that is, some lesions are RAI-avid and others are not); or disease that progresses after RAI treatment despite RAI uptake $^{12}$. Specific molecular profiles are more likely to result in RAI-refractory disease ${ }^{60,61}$. Even in the presence of distant metastases, most patients have asymptomatic, slowly progressive disease. RAI-refractory patients should benefit from local treatments (surgery, external beam radiotherapy, or thermal ablation, depending on the site of the lesion and local expertise) if they have symptoms or a high risk of local complications.

When disease progression occurs at multiple sites in patients with target lesions of more than 1-2 cm in diameter, treatment with tyrosine kinase inhibitors (TKIs) should be considered.

Two multitarget TKIs have been approved for the treatment of RAI-refractory DTC in the United States and Europe: sorafenib and lenvatinib ${ }^{62,63}$. These drugs have been shown to prolong the progression-free survival of patients with progressive RAI-refractory DTC, as compared with placebo (10.8 versus 5.8 months, hazard ratio [HR] 0.59 for sorafenib; 18.3 versus 3.6 months, HR 0.21 for lenvatinib), and objective response rates were $12 \%$ and $65 \%$, respectively ${ }^{62,63}$. However, multitarget TKIs have side effects ${ }^{64}$. Greater experience in their use and better knowledge of the risk factors for these adverse effects ${ }^{65,66}$ are likely to improve their tolerance.

For BRAF- or ALK-mutant tumors, specific inhibitors may be used $^{64,67}$. Treatments capable of restoring RAI uptake have attracted great interest. Selumetinib (a selective MEK inhibitor) and dabrafenib (a selective BRAF inhibitor used in BRAF-mutated tumors) have been shown to increase RAI uptake by RAI-refractory tumor tissues ${ }^{68,69}$, and these encouraging results are now under investigation (NCT02393690 and NCT03244956). Immunotherapy also appears to be a promising approach to thyroid cancer, alone or in association with other $\operatorname{drugs}^{70}$ (NCT02390739 
and NCT03181100). These agents have yet to be approved by regulatory agencies, such as the U.S. Food and Drug Administration and the European Medicines Agency. Enrollment in clinical trials for patients with progressive metastatic disease should be considered and encouraged in order to improve both clinical case outcomes and medical knowledge in the field ${ }^{71}$.

\section{Conclusions}

In recent years, DTC treatment has become considerably more conservative, with less extensive surgery (or no surgery at all), reduced use of radioisotopes, and less intensive follow-up of low- and intermediate-risk patients. Furthermore, the systems used to histologically classify and stage DTCs have recently been refined, along with the ATA scheme for estimating their risk of recurrence, and more patients are now considered to be at low or intermediate risk. There is a need for new, prospective data to clarify how these changing practices will impact the long-term outcome of these patients. On the other hand, patients with more advanced or high-risk disease now have a broader portfolio of treatment options, including multitarget TKI therapy, more selective BRAF inhibitors, combination therapies, and immunotherapy. However, the indications for each, their optimal starting times and dosing schedules, and their long-term safety profiles remain to be clarified in coming years.

\section{Abbreviations}

ATA, American Thyroid Association; DTC, differentiated thyroid carcinoma; FNA, fine-needle aspiration; FTC, follicular thyroid cancer; HR, hazard ratio; NIFTP, non-invasive follicular thyroid neoplasm with papillary nuclear features; PTC, papillary thyroid carcinoma; RAI, radioactive iodine; rhTSH, recombinant human thyroid-stimulating hormone; RLN, recurrent laryngeal nerve; Tg, thyroglobulin; TgAb, thyroglobulin autoantibody; TKI, tyrosine kinase inhibitor; TL, thyroid lobectomy; TNM, tumor, node, and metastasis; TSH, thyroid-stimulating hormone; TT, total thyroidectomy; US, ultrasound; WBS, whole-body scan.

\section{Competing interests}

The authors declare that they have no competing interests.

\section{Grant information}

The author(s) declared that no grants were involved in supporting this work.

\section{Acknowledgments}

GG and LL contributed to this article as recipients of the $\mathrm{PhD}$ program of Biotechnologies and Clinical Medicine of the Sapienza University of Rome.
1. WHO Classification of Tumours of Endocrine Organs. Fourth Edition ed Geneve: World Health Organization; 2017. Reference Source

2. F Haugen BR, Sawka AM, Alexander EK, et al:: American Thyroid Association Guidelines on the Management of Thyroid Nodules and Differentiated Thyroid Cancer Task Force Review and Recommendation on the Proposed Renaming of Encapsulated Follicular Variant Papillary Thyroid Carcinoma Without Invasion to Noninvasive Follicular Thyroid Neoplasm with Papillary-Like Nuclear Features. Thyroid. 2017; 27(4): 481-3. PubMed Abstract | Publisher Full Text | F1000 Recommendation

3. Nikiforov YE, Seethala RR, Tallini G, et al:: Nomenclature Revision for Encapsulated Follicular Variant of Papillary Thyroid Carcinoma: A Paradigm Shift to Reduce Overtreatment of Indolent Tumors. JAMA Oncol. 2016; 2(8): 1023-9.

PubMed Abstract | Publisher Full Text | Free Full Text

4. Grani G, Lamartina L, Durante C, et al.: Follicular thyroid cancer and Hürthle cell carcinoma: challenges in diagnosis, treatment, and clinical management. Lancet Diabetes Endocrinol. 2017; pii: S2213-8587(17)30325-X. PubMed Abstract | Publisher Full Text

5. Volante M, Collini P, Nikiforov YE, et al:: Poorly differentiated thyroid carcinoma: the Turin proposal for the use of uniform diagnostic criteria and an algorithmic diagnostic approach. Am J Surg Pathol. 2007; 31(8): 1256-64. PubMed Abstract | Publisher Full Text

6. Volante M, Bussolati G, Papotti M: The story of poorly differentiated thyroid carcinoma: From Langhans' description to the Turin proposal via Juan Rosai. Semin Diagn Pathol. 2016; 33(5): 277-83. PubMed Abstract | Publisher Full Text

7. F Nixon IJ, Wang LY, Migliacci JC, et al.: An International Multi-Institutional Validation of Age 55 Years as a Cutoff for Risk Stratification in the AJCC/UICC Staging System for Well-Differentiated Thyroid Cancer. Thyroid. 2016; 26(3): 373-80.

PubMed Abstract | Publisher Full Text | Free Full Text | F1000 Recommendation

8. $\mathrm{F} \mathrm{Kim} \mathrm{TH,} \mathrm{Kim} \mathrm{YN,} \mathrm{Kim} \mathrm{HI,} \mathrm{et} \mathrm{al.:} \mathrm{Prognostic} \mathrm{value} \mathrm{of} \mathrm{the} \mathrm{eighth} \mathrm{edition} \mathrm{AJCC}$ TNM classification for differentiated thyroid carcinoma. Oral Oncol. 2017; 71 $81-6$.

PubMed Abstract | Publisher Full Text | F1000 Recommendation
9. F Kim M, Kim WG, Oh HS, et al:: Comparison of the Seventh and Eighth Editions of the American Joint Committee on Cancer/Union for International Cancer Control Tumor-Node-Metastasis Staging System for Differentiated Thyroid Cancer. Thyroid. 2017; 27(9): 1149-55. PubMed Abstract | Publisher Full Text | F1000 Recommendation

10. F Tuttle RM, Haugen B, Perrier ND: Updated American Joint Committee on Cancer/Tumor-Node-Metastasis Staging System for Differentiated and Anaplastic Thyroid Cancer (Eighth Edition): What Changed and Why? Thyroid. 2017; 27(6): 751-6.

PubMed Abstract | Publisher Full Text | Free Full Text | F1000 Recommendation

11. de Biase D, Gandolfi G, Ragazzi M, et al.: TERT Promoter Mutations in Papillary Thyroid Microcarcinomas. Thyroid. 2015; 25(9): 1013-9. PubMed Abstract | Publisher Full Text

12. F Haugen BR, Alexander EK, Bible KC, et al:: 2015 American Thyroid Association Management Guidelines for Adult Patients with Thyroid Nodules and Differentiated Thyroid Cancer: The American Thyroid Association Guidelines Task Force on Thyroid Nodules and Differentiated Thyroid Cancer. Thyroid. 2016; 26(1): 1-133.

PubMed Abstract | Publisher Full Text | Free Full Text | F1000 Recommendation

13. Ito $\mathrm{Y}$, Miyauchi $\mathrm{A}$, Inoue $\mathrm{H}$, et al:: An observational trial for papillary thyroid microcarcinoma in Japanese patients. World J Surg. 2010; 34(1): 28-35. PubMed Abstract | Publisher Full Text

14. F Oda H, Miyauchi A, Ito $\mathrm{Y}$, et al:: Incidences of Unfavorable Events in the Management of Low-Risk Papillary Microcarcinoma of the Thyroid by Active Surveillance Versus Immediate Surgery. Thyroid. 2016; 26(1): 150-5. PubMed Abstract | Publisher Full Text | Free Full Text | F1000 Recommendation

15. $\mathrm{F}$ Ito $\mathrm{Y}$, Miyauchi $\mathrm{A}$, Kihara $\mathrm{M}$, et al:: Patient age is significantly related to the progression of papillary microcarcinoma of the thyroid under observation. Thyroid. 2014; 24(1): 27-34.

PubMed Abstract | Publisher Full Text | Free Full Text | F1000 Recommendation

16. F Tuttle RM, Fagin JA, Minkowitz G, et al:: Natural History and Tumor Volume Kinetics of Papillary Thyroid Cancers During Active Surveillance. JAMA Otolaryngol Head Neck Surg. 2017; 143(10): 1015-20. PubMed Abstract | Publisher Full Text | Free Full Text | F1000 Recommendation

17. $\mathrm{F}$ Brito JP, Ito $\mathrm{Y}$, Miyauchi A, et al:: A Clinical Framework to Facilitate 
Risk Stratification When Considering an Active Surveillance Alternative to Immediate Biopsy and Surgery in Papillary Microcarcinoma. Thyroid. 2016; 26(1): 144-9.

PubMed Abstract | Publisher Full Text | Free Full Text | F1000 Recommendation

18. Bilimoria $\mathrm{KY}$, Bentrem $\mathrm{DJ}, \mathrm{Ko} \mathrm{CY}$, et al:: Extent of surgery affects survival for papillary thyroid cancer. Ann Surg. 2007; 246(3): 375-81; discussion 381-4. PubMed Abstract | Publisher Full Text | Free Full Text

19. F Adam MA, Pura J, Goffredo $P$, et al.: Impact of extent of surgery on survival for papillary thyroid cancer patients younger than $\mathbf{4 5}$ years. J Clin Endocrinol Metab. 2015; 100(1): 115-21.

PubMed Abstract | Publisher Full Text | Free Full Text | F1000 Recommendation

20. F Macedo FI, Mittal VK: Total thyroidectomy versus lobectomy as initial operation for small unilateral papillary thyroid carcinoma: A meta-analysis. Surg Oncol. 2015; 24(2): 117-22.

PubMed Abstract | Publisher Full Text | F1000 Recommendation

21. F Matsuzu K, Sugino K, Masudo K, et al:: Thyroid lobectomy for papillary thyroid cancer: long-term follow-up study of 1,088 cases. World J Surg. 2014; 38(1): 68-79.

PubMed Abstract | Publisher Full Text | F1000 Recommendation

22. Antunes $\mathrm{CM}$, Taveira-Gomes $\mathrm{A}$ : Lobectomy in follicular thyroid neoplasms treatment. Int J Surg. 2013; 11(9): 919-22.

PubMed Abstract | Publisher Full Tex

23. F Lytrivi M, Kyrilli A, Burniat A, et al:: Thyroid lobectomy is an effective option for unilateral benign nodular disease. Clin Endocrinol (Oxf). 2016; 85(4): 602-8. PubMed Abstract | Publisher Full Text | F1000 Recommendation

24. Alba M, Fintini D, Lovicu RM, et al.: Levothyroxine therapy in preventing nodular recurrence after hemithyroidectomy: a retrospective study. J Endocrinol Invest. 2009; 32(4): 330-4.

PubMed Abstract | Publisher Full Text

25. Rosato L, Avenia N, Bernante $\mathrm{P}$, et al:: Complications of thyroid surgery: analysis of a multicentric study on 14,934 patients operated on in Italy over 5 years. World J Surg. 2004; 28(3): 271-6.

PubMed Abstract | Publisher Full Text

26. Balentine CJ, Domingo RP, Patel R, et al:: Thyroid lobectomy for indeterminate FNA: not without consequences. J Surg Res. 2013; 184(1): 189-92. PubMed Abstract | Publisher Full Text

27. Lee DY, Seok J, Jeong WJ, et al:: Prediction of thyroid hormone supplementation after thyroid lobectomy. J Surg Res. 2015; 193(1): 273-8. PubMed Abstract | Publisher Full Text

28. Malterling RR, Andersson RE, Falkmer S, et al.: Differentiated thyroid cancer in a Swedish county--long-term results and quality of life. Acta Oncol. 2010; 49(4): 454-9.

PubMed Abstract | Publisher Full Text

29. Shah MD, Witterick IJ, Eski SJ, et al:: Quality of life in patients undergoing thyroid surgery. J Otolaryngol. 2006; 35(4): 209-15.

PubMed Abstract

30. Wada N, Duh QY, Sugino K, et al.: Lymph node metastasis from 259 papillary thyroid microcarcinomas: frequency, pattern of occurrence and recurrence, and optimal strategy for neck dissection. Ann Surg. 2003; 237(3): 399-407. PubMed Abstract | Publisher Full Text | Free Full Text

31. Randolph GW, Duh Q, Heller KS, et al.: The prognostic significance of nodal metastases from papillary thyroid carcinoma can be stratified based on the size and number of metastatic lymph nodes, as well as the presence of extranodal extension. Thyroid. 2012; 22(11): 1144-52.

PubMed Abstract | Publisher Full Text

32. Viola D, Materazzi G, Valerio L, et al:: Prophylactic central compartment lymph node dissection in papillary thyroid carcinoma: clinical implications derived from the first prospective randomized controlled single institution study. J Clin Endocrinol Metab. 2015; 100(4): 1316-24.

PubMed Abstract | Publisher Full Text

33. Lee DY, Oh KH, Cho JG, et al.: The Benefits and Risks of Prophylactic Central Neck Dissection for Papillary Thyroid Carcinoma: Prospective Cohort Study. Int J Endocrinol. 2015; 2015: 571480. PubMed Abstract | Publisher Full Text | Free Full Text

34. F American Thyroid Association (ATA) Guidelines Taskforce on Thyroid Nodules and Differentiated Thyroid Cancer, Cooper DS, Doherty GM, et al.: Revised American Thyroid Association management guidelines for patients with thyroid nodules and differentiated thyroid cancer. Thyroid. 2009; 19(11): thyroid nodul

1167-214.
PubMed Abstract | Publisher Full Text | F1000 Recommendation

35. Lamartina L, Durante C, Filetti S, et al.: Low-risk differentiated thyroid cance and radioiodine remnant ablation: a systematic review of the literature. $J$ Clin Endocrinol Metab. 2015; 100(5): 1748-61. PubMed Abstract | Publisher Full Text

36. F Verburg FA, Aktolun C, Chiti A, et al:: Why the European Association of Nuclear Medicine has declined to endorse the 2015 American Thyroid Association management guidelines for adult patients with thyroid nodules and differentiated thyroid cancer. Eur J Nucl Med Mol Imaging. 2016; 43(6) $1001-5$

PubMed Abstract | Publisher Full Text | F1000 Recommendation

37. F Schlumberger M, Catargi B, Borget I, et al.: Strategies of radioiodine ablation in patients with low-risk thyroid cancer. N Engl J Med. 2012; 366(18): 1663-73. PubMed Abstract | Publisher Full Text | F1000 Recommendation

38. Durante $\mathrm{C}$, Attard $\mathrm{M}$, Torlontano $\mathrm{M}$, et al:: Identification and optimal postsurgical follow-up of patients with very low-risk papillary thyroid microcarcinomas. J Clin Endocrinol Metab. 2010; 95(11): 4882-8.

PubMed Abstract | Publisher Full Text

39. Vaisman $\mathrm{F}$, Momesso D, Bulzico DA, et al:: Spontaneous remission in thyroid cancer patients after biochemical incomplete response to initial therapy. Clin Endocrinol (Oxf). 2012; 77(1): 132-8.

PubMed Abstract | Publisher Full Text

40. Durante $\mathrm{C}$, Montesano $\mathrm{T}$, Attard $\mathrm{M}$, et al: : Long-term surveillance of papillary thyroid cancer patients who do not undergo postoperative radioiodine remnant ablation: is there a role for serum thyroglobulin measurement? J Clin Endocrinol Metab. 2012; 97(8): 2748-53. PubMed Abstract | Publisher Full Text

41. Durante $\mathrm{C}$, Tognini S, Montesano T, et al.: Clinical aggressiveness and long term outcome in patients with papillary thyroid cancer and circulating antithyroglobulin autoantibodies. Thyroid. 2014; 24(7): 1139-45. PubMed Abstract | Publisher Full Text | Free Full Text

42. Rosignolo F, Memeo L, Monzani F, et al:: MicroRNA-based molecular classification of papillary thyroid carcinoma. Int J Oncol. 2017; 50(5): 1767-77. PubMed Abstract | Publisher Full Text

43. Rosignolo F, Sponziello M, Giacomelli L, et al:: Identification of ThyroidAssociated Serum microRNA Profiles and Their Potential Use in Thyroid Cancer Follow-Up. J Endocr Soc. 2017; 1(1): 3-13. PubMed Abstract | Publisher Full Text | Free Full Text

44. F Celano M, Rosignolo F, Maggisano V, et al:: MicroRNAs as Biomarkers in Thyroid Carcinoma. Int J Genomics. 2017; 2017: 6496570. PubMed Abstract | Publisher Full Text | Free Full Text | F1000 Recommendation

45. F Netzel BC, Grebe SK, Carranza Leon BG, et al.: Thyroglobulin (Tg) Testing Revisited: Tg Assays, TgAb Assays, and Correlation of Results With Clinical Outcomes. J Clin Endocrinol Metab. 2015; 100(8): E1074-83. PubMed Abstract | Publisher Full Text | Free Full Text | F1000 Recommendation

46. F Azmat U, Porter K, Senter L, et al:: Thyroglobulin Liquid ChromatographyTandem Mass Spectrometry Has a Low Sensitivity for Detecting Structural Disease in Patients with Antithyroglobulin Antibodies. Thyroid. 2017; 27(1) $74-80$.

PubMed Abstract | Publisher Full Text | Free Full Text | F1000 Recommendation

47. $\mathrm{F}$ Brassard M, Borget I, Edet-Sanson A, et al:: Long-term follow-up of patients with papillary and follicular thyroid cancer: a prospective study on $\mathbf{7 1 5}$ patients. $J$ Clin Endocrinol Metab. 2011; 96(5): 1352-9.

PubMed Abstract | Publisher Full Text | F1000 Recommendation

48. Leenhardt L, Erdogan MF, Hegedus L, et al:: 2013 European thyroid association guidelines for cervical ultrasound scan and ultrasound-guided techniques in the postoperative management of patients with thyroid cancer. Eur Thyroid $J$. 2013; 2(3): 147-59.

PubMed Abstract | Publisher Full Text | Free Full Text

49. Lamartina L, Grani G, Biffoni M, et al.: Risk Stratification of Neck Lesions Detected Sonographically During the Follow-Up of Differentiated Thyroid Cancer. J Clin Endocrinol Metab. 2016; 101(8): 3036-44. PubMed Abstract | Publisher Full Text

50. Grani G, Fumarola A: Thyroglobulin in lymph node fine-needle aspiration washout: a systematic review and meta-analysis of diagnostic accuracy. $J$ Clin Endocrinol Metab. 2014: 99(6): 1970-82. PubMed Abstract | Publisher Full Text

51. Lamartina L, Deandreis D, Durante C, et al.: ENDOCRINE TUMOURS: Imaging in the follow-up of differentiated thyroid cancer: current evidence and future perspectives for a risk-adapted approach. Eur J Endocrinol. 2016; 175(5): R185-202. PubMed Abstract | Publisher Full Text

52. $\mathrm{F}$ Tuttle $\mathrm{RM}, \mathrm{Tala} \mathrm{H}, \mathrm{Shah} \mathrm{J}$, et al.: Estimating risk of recurrence in differentiated thyroid cancer after total thyroidectomy and radioactive iodine remnant ablation: using response to therapy variables to modify the initial risk estimates predicted by the new American Thyroid Association staging system. Thyroid. 2010; 20(12): 1341-9.

PubMed Abstract | Publisher Full Text | Free Full Text | F1000 Recommendation

53. Durante $\mathrm{C}$, Montesano $\mathrm{T}$, Torlontano $\mathrm{M}$, et al:: Papillary thyroid cancer: time course of recurrences during postsurgery surveillance. J Clin Endocrinol Metab. 2013; 98(2): 636-42.

PubMed Abstract | Publisher Full Text

54. Biondi B, Filetti S, Schlumberger M: Thyroid-hormone therapy and thyroid cancer: a reassessment. Nat Clin Pract Endocrinol Metab. 2005; 1(1): 32-40. PubMed Abstract | Publisher Full Text

55. Mazzaferri EL, Kloos RT: Clinical review 128: Current approaches to primary therapy for papillary and follicular thyroid cancer. J Clin Endocrinol Metab. 2001; 86(4): 1447-63.

PubMed Abstract | Publisher Full Text

56. Biondi B, Cooper DS: Benefits of thyrotropin suppression versus the risks of adverse effects in differentiated thyroid cancer. Thyroid. 2010; 20(2): 135-46.

PubMed Abstract | Publisher Full Text 
57. Klubo-Gwiezdzinska J, Burman KD, van Nostrand D, et al.: Potential use of recombinant human thyrotropin in the treatment of distant metastases in patients with differentiated thyroid cancer. Endocr Pract. 2013; 19(1): 139-48. PubMed Abstract | Publisher Full Text | Free Full Text

58. F Deandreis D, Rubino C, Tala H, et al:: Comparison of Empiric Versus WholeBody/-Blood Clearance Dosimetry-Based Approach to Radioactive lodine Treatment in Patients with Metastases from Differentiated Thyroid Cancer. J Nucl Med. 2017; 58(5): 717-22.

PubMed Abstract | Publisher Full Text | F1000 Recommendation

59. Durante C, Haddy N, Baudin E, et al:: Long-term outcome of $\mathbf{4 4 4}$ patients with distant metastases from papillary and follicular thyroid carcinoma: benefits and limits of radioiodine therapy. J Clin Endocrinol Metab. 2006; 91(8): 2892-9. PubMed Abstract | Publisher Full Text

60. Xing $M$, Westra $\mathrm{WH}$, Tufano RP, et al.: BRAF mutation predicts a poorer clinical prognosis for papillary thyroid cancer. J Clin Endocrinol Metab. 2005; 90(12): 6373-9.

PubMed Abstract | Publisher Full Text

61. Durante $\mathrm{C}$, Puxeddu E, Ferretti E, et al:: BRAF mutations in papillary thyroid carcinomas inhibit genes involved in iodine metabolism. J Clin Endocrinol Metab. 2007; 92(7): 2840-3.

PubMed Abstract | Publisher Full Text

62. F Schlumberger $M$, Tahara $M$, Wirth $L J$, et al:: Lenvatinib versus placebo in radioiodine-refractory thyroid cancer. N Engl J Med. 2015; 372(7): 621-30. PubMed Abstract | Publisher Full Text | F1000 Recommendation

63. Brose MS, Nutting CM, Jarzab B, et al:: Sorafenib in radioactive iodinerefractory, locally advanced or metastatic differentiated thyroid cancer: a randomised, double-blind, phase 3 trial. Lancet. 2014; 384(9940): 319-28. PubMed Abstract | Publisher Full Text | Free Full Text
64. Cabanillas ME, McFadden DG, Durante C: Thyroid cancer. Lancet. 2016; 388(10061): 2783-95. PubMed Abstract | Publisher Full Text

65. Lamartina L, Ippolito S, Danis M, et al:: Antiangiogenic Tyrosine Kinase Inhibitors: Occurrence and Risk Factors of Hemoptysis in Refractory Thyroid Cancer. J Clin Endocrinol Metab. 2016; 101(7): 2733-41. PubMed Abstract | Publisher Full Text

66. Blevins DP, Dadu R, Hu M, et al:: Aerodigestive fistula formation as a rare side effect of antiangiogenic tyrosine kinase inhibitor therapy for thyroid cancer. Thyroid. 2014; 24(5): 918-22. PubMed Abstract | Publisher Full Text | Free Full Text

67. F Cabanillas ME, Patel A, Danysh BP, et al:: : BRAF inhibitors: experience in thyroid cancer and general review of toxicity. Horm Cancer. 2015; 6(1): 21-36. PubMed Abstract | Publisher Full Text | Free Full Text | F1000 Recommendation

68. F Ho AL, Grewal RK, Leboeuf R, et al:: Selumetinib-enhanced radioiodine uptake in advanced thyroid cancer. N Engl J Med. 2013; 368(7): 623-32. PubMed Abstract | Publisher Full Text | Free Full Text | F1000 Recommendation

69. F Rothenberg SM, Daniels GH, Wirth LJ: Redifferentiation of lodine-Refractory BRAF V600E-Mutant Metastatic Papillary Thyroid Cancer with DabrafenibResponse. Clin Cancer Res. 2015; 21(24): 5640-1. PubMed Abstract | Publisher Full Text | F1000 Recommendation

70. F French JD, Bible K, Spitzweg C, et al:: Leveraging the immune system to treat advanced thyroid cancers. Lancet Diabetes Endocrinol. 2017; 5(6): 469-81. PubMed Abstract | Publisher Full Text | F1000 Recommendation

71. Bible KC, Cote GJ, Demeure MJ, et al: Correlative Studies in Clinical Trials: A Position Statement From the International Thyroid Oncology Group. J Clin Endocrinol Metab. 2015; 100(12): 4387-95.

PubMed Abstract | Publisher Full Text | Free Full Text 


\section{Open Peer Review}

\section{Current Peer Review Status:}

\section{Editorial Note on the Review Process}

Faculty Reviews are review articles written by the prestigious Members of Faculty Opinions. The articles are commissioned and peer reviewed before publication to ensure that the final, published version is comprehensive and accessible. The reviewers who approved the final version are listed with their names and affiliations.

\section{The reviewers who approved this article are:}

\section{Version 1}

\section{Iain Nixon}

Ear, nose and throat (ENT) Department, NHS Lothian, Edinburgh, UK

Competing Interests: No competing interests were disclosed.

\section{Matthew Ringel}

Division of Endocrinology, Diabetes, and Metabolism, The Ohio State University Medical Center, Columbus, $\mathrm{OH}$, USA

Competing Interests: No competing interests were disclosed.

The benefits of publishing with F1000Research:

- Your article is published within days, with no editorial bias

- You can publish traditional articles, null/negative results, case reports, data notes and more

- The peer review process is transparent and collaborative

- Your article is indexed in PubMed after passing peer review

- Dedicated customer support at every stage

For pre-submission enquiries, contact research@f1000.com

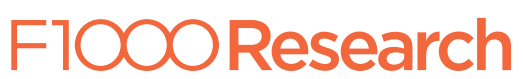

